\title{
Student-framed Inquiry in a Multidisciplinary Bachelor Course at a Dutch University of Applied Sciences
}

\begin{abstract}
When students explore their own open questions, they learn to be proactive and see themselves not only as consumers but also as producers of knowledge. Such student-framed inquiry has received less research attention. This article aims to shed light on learning outcomes and effects on students' mind-set and behavior by discussing a course that fosters student-framed inquiry. The one-semester, elective course was open to third- and fourth-year students of various bachelor's-level programs. A questionnaire was sent to alumni after 11 iterations of the course. The results showed that the course fostered the development of skills in innovation, networking, and cross-boundary collaboration and learning, as well as enhanced personal and professional development. Students became more proactive, less afraid to contact people and take steps to make things happen. The results suggest that courses for inquiry-based learning should include not only more traditional, discipline-oriented research skills and methods but also student-framed methods for design and discovery.
\end{abstract}

Keywords: undergraduate research, student-framed inquiry, design thinking, student engagement, inquiry-based learning

\section{Introduction}

Institutions for higher and vocational education are challenged to educate "knowledge workers"-professionals who are able to solve complex problems collaboratively across disciplines, professions, and perspectives. These knowledge workers are also lifelong learners who acquire and develop knowledge throughout their working life (Tynjälä 1999). As Brew (2010) notes, "The demands of today's society require higher education to open up to creative solutions to the generation and acquisition of new kinds of knowledge, to new kinds of thinking."

A possible instruction strategy for fostering knowledge-building capabilities in students is inquiry-based learning (IBL). Levy (2011, 36-37) defines IBL as "a cluster of related pedagogies in which student inquiry or research drives the experience of learning through participation in knowledge building." Increasingly, this participation is realized by offering students the opportunity to engage in problems or issues in professional practice or the community (such as by service learning or community learning programs).
There is a growing body of research on students' engagement in research and inquiry that focuses on students exploring questions posed by others such as lecturers, community-based stakeholders, or researchers. However, when students explore their own open questions, problems, scenarios, or lines of inquiry, they learn to be proactive and see themselves not only as consumers but also as producers of knowledge (Neary 2014; Healey and Jenkins 2009). Levy $(2011,39)$ calls this mode of IBL "student-framed inquiry" (SFI), which ideally focuses on discovery-oriented learning (Spronken-Smith and Walker 2010).

Instructional design for student-framed inquiry has not yet received much research attention. Therefore, this article aims to shed light on learning outcomes and effects on students' mind-set and behavior after they attended a bachelor's-level course focusing on SFI. This leads to the main research question: Which learning outcomes and effects on students' mind-set and behavior can be achieved through a course designed for student-framed inquiry?

To address this research question, the concept of student-framed inquiry and the design of the course will be described. Next, the research method and findings will be presented, followed by conclusions and a reflective discussion.

\section{Student-framed Inquiry}

SFI is defined here as "knowledge building that is aimed at addressing a self-chosen problem or issue in professional practice or society through collaboration with peers and relevant stakeholders." Undergraduate students of a university of applied sciences (UAS) in the Netherlands are the focus of this article. A UAS, also called a vocational university, professional university, or college of higher vocational studies, is an institution of higher education. In the Netherlands, a UAS (referred to in Dutch as a "hogeschool") grants professional bachelor's and master's degrees (see Figure 1). These universities focus on professional practice and practice-based research. The duration of a professional bachelor's program is typically four years; a master's program usually takes one to two years of study (EP-Nuffic 2016).

The Council on Undergraduate Research (2016) describes undergraduate research as "an inquiry or investigation conducted by an undergraduate student that makes an original intellectual or creative contribution to the discipline." However, several authors such as Healey and colleagues (2014), Levy 
Figure 1. The Dutch Educational System

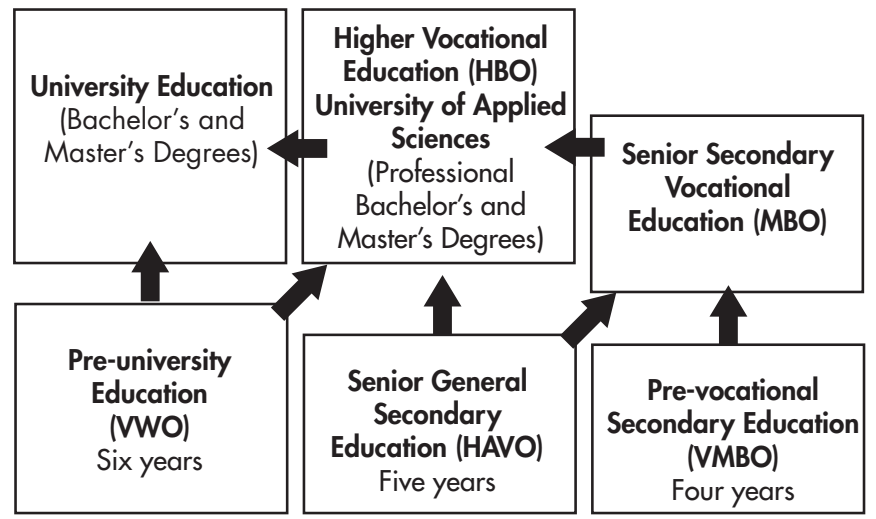

(2011), and Andriessen (2014) argue that "making an original contribution" raises the bar too high. Although more students probably are capable of operating at this level than many faculty may believe, it seems more appropriate to define the "intellectual and creative contribution" for the bachelor's level as new knowledge for the student, the relevant stakeholder(s), or client but not necessarily new knowledge for society.

At universities of applied sciences, SFI is usually grounded in professional practice or the community. Practice-based research and inquiry yields an intellectual and creative contribution to a certain body of knowledge and to practice. This implies that the outcomes are usually twofold: a new or improved professional product and new knowledge. Professional product is defined broadly here. A product is understood here as a practical solution that can take the form of a tangible artifact but also of a design, an intervention, a set of guidelines, and so forth. New knowledge encompasses not only new insights, which may include scientific knowledge that is acquired through research, but also expert or craft knowledge, or knowledge that is embodied in creative innovations.

Methods for realizing new insights along with practical solutions often require a combination of design and research (Stappers 2007). In such a process of design-based inquiry, ideas, concepts, or products are developed and evaluated. A possible method that supports this process is "design thinking" (Brown 2009). Design thinking is a systematic strategy for developing creative ideas, concepts, or products. The main stages in the strategy for the designer(s) are empathize (find out what is really at stake), define (the problem or challenge), ideate (generate ideas for possible solutions), prototype (build physical props of the solution), and test (evaluate the effectiveness of the solution). These stages are interconnected and are of a cyclic nature. Prototypes are used in various stages of development. Prototyping, or "thinking with your hands," entails the use of physical props as a springboard for the imagination, as Brown $(2009,87)$ notes: "This shift from physical to abstract and back again is one of the most fundamental processes by which we explore the universe, unlock our imaginations, and open our minds to new possibilities." Prototypes can take many forms, such as sketches, role plays, scenarios, or artifacts.

In sum, student-framed inquiry at the bachelor level is a practice-based inquiry of a self-chosen problem or issue, and design thinking is considered as a method that can support this process.

\section{The Aims, Context, and Design of a Course for Fostering Student-framed Inquiry}

The course, also called the "Da Vinci Minor," is aimed at educating "knowledge workers"-that is, entrepreneurial, innovative, and creative professionals who are able to direct their own personal and professional development in an ongoing manner. To fulfill this goal, students work on a self-chosen problem or issue in professional practice or society through open inquiry in collaboration with peers and relevant stakeholders. The overall learning outcomes are described in the student guide as five "job requirements" for a knowledge worker, which are presented in Table 1 (Instituut voor Marketing Management 2014).

Table 1. "Job Requirements" for a Knowledge Worker

\begin{tabular}{|c|c|}
\hline Requirement & Description \\
\hline $\begin{array}{l}\text { Skills in } \\
\text { Innovation }\end{array}$ & $\begin{array}{l}\text { Always looking for new combinations, contributing } \\
\text { to building new knowledge, and demonstrating } \\
\text { ability to let go of paradigms or frames of reference. } \\
\text { Applying methods that foster creativity such as } \\
\text { developing prototypes and testing them with relevant } \\
\text { stakeholders. }\end{array}$ \\
\hline $\begin{array}{l}\text { Cross- } \\
\text { boundary } \\
\text { Collaboration } \\
\text { and Learning }\end{array}$ & $\begin{array}{l}\text { Expanding personal expertise and connecting with } \\
\text { other people's expertise. Being a team player and } \\
\text { utilizing diversity in a group. Contributing to the } \\
\text { team and helping others to learn, including offering } \\
\text { and receiving constructive feedback. }\end{array}$ \\
\hline Networking & $\begin{array}{l}\text { Initiating and utilizing formal and informal networks; } \\
\text { forming partnerships with relevant stakeholders. }\end{array}$ \\
\hline $\begin{array}{l}\text { Professional } \\
\text { Behavior }\end{array}$ & $\begin{array}{l}\text { Taking responsibility for personal actions, taking } \\
\text { into account organization, environment, and society. } \\
\text { Behavior is attuned to context and to others. Always } \\
\text { seeking dialogue and communicating values and } \\
\text { standards. }\end{array}$ \\
\hline $\begin{array}{l}\text { Personal and } \\
\text { Professional } \\
\text { Development }\end{array}$ & $\begin{array}{l}\text { Always looking for opportunities to develop person- } \\
\text { ally and professionally. Insight into own personality, } \\
\text { including strengths and weaknesses. Able to reflect } \\
\text { on functioning and open to feedback. Able to make } \\
\text { explicit what has been learned. }\end{array}$ \\
\hline
\end{tabular}


Third- and fourth-year students of all bachelor's-level programs at Hanze UAS in the Netherlands can enroll in this one-semester elective course for 30 study credits (European Credit Transfer System). Class size varies between 15 and 30 students. Three lecturers and an entrepreneur compose the course faculty. The faculty members work as a team and have competencies in design thinking, coaching, and (self-) reflection.

The course design was based on seven design principles of "hybrid learning configurations" (HLC). An HLC can be characterized as a learning environment at the interface between school and workplace in which students from different study programs work on ill-defined, authentic tasks or issues in professional practice or the community (Cremers et al. 2016). The design principles and examples of corresponding features of the course are described in Table 2 .

Table 2. Design Principles and Features of the Course

\section{Main Features of the Course}

Before the course begins, each student meets with one of the lecturers as well as with students enrolled in the current course (the lecturer does not attend the latter meeting). The lecturer focuses on the main characteristics of an innovative professional: creative, collaborative, result-oriented, curious, enthusiastic, proactive, and focused on personal and professional development. The pedagogic approach of discovery-oriented learning and the lecturer as a coach and facilitator also is discussed. Through this process, students can decide for themselves if they are committed to participate in the course.

The students choose their own subject of inquiry. Products can be tangible artifacts as well as concepts, designs, procedures, or guidelines. The complexity of the projects varies greatly among students. In the history of the course, students have improved existing products or designed completely new initiatives in an international context. The level

\begin{tabular}{|c|c|}
\hline Design Principle & ures of the Course \\
\hline $\begin{array}{l}\text { Fostering } \\
\text { Authenticity }\end{array}$ & $\begin{array}{l}\text { Learning is driven by questions or problems in society. } \\
\text { Students apply methods such as design thinking to find answers in the form of knowledge and products. } \\
\text { Students initiate their own projects, engage stakeholders in the community, and field-test prototypes of their solutions to problems } \\
\text { in practice. }\end{array}$ \\
\hline $\begin{array}{l}\text { Interlinking of } \\
\text { Working and } \\
\text { Learning }\end{array}$ & $\begin{array}{l}\text { Students learn by doing, discovering, and making mistakes. } \\
\text { Lecturers act mainly as facilitator or coach. } \\
\text { Educational interventions include coaching during project work, peer feedback, and feedback from experts and lecturers. } \\
\text { Lecturers occasionally provide workshops on topics such as self-directed learning and design thinking. } \\
\text { Students organize workshops for each other on study materials related to student-framed inquiry and invite experts to give } \\
\text { lectures or workshops. } \\
\text { Lecturers assess the students' work, focusing mainly on the processes (design thinking, self-directed learning) and less on the } \\
\text { specific outcomes. }\end{array}$ \\
\hline Utilizing Diversity & $\begin{array}{l}\text { Students work alone or in small teams (the latter is encouraged) consisting of students enrolled in different study programs. } \\
\text { Students are encouraged to form networks of peers and professionals involved in their topic of investigation. }\end{array}$ \\
\hline $\begin{array}{l}\text { Facilitating } \\
\text { Reflexivity }\end{array}$ & $\begin{array}{l}\text { Students learn to set their own learning goals, monitor their learning, and make their learning results explicit. } \\
\text { Students write weekly logs in which they reflect on critical events that provided learning opportunities. } \\
\text { Students offer each other feedback on their self-directed learning activities in peer groups that are initially facilitated by a } \\
\text { lecturer but are increasingly run by the students. } \\
\text { Students write learning reports twice during the course and present their personal learning outcomes to each other and the lecturers. }\end{array}$ \\
\hline $\begin{array}{l}\text { Creating a } \\
\text { Learning } \\
\text { Community }\end{array}$ & $\begin{array}{l}\text { Students provide peer feedback and support each other in their project work. } \\
\text { Students create their own culture and set of rules that reflects a professional working culture and a sense of community. } \\
\text { Lecturers are also learners and solicit feedback from each other and students. }\end{array}$ \\
\hline $\begin{array}{l}\text { Enabling } \\
\text { Organization }\end{array}$ & Students have their own working space that they are allowed to decorate themselves. \\
\hline Enabling Ecology & $\begin{array}{l}\text { Enrollment in the course is preceded by an interview to foster commitment and manage expectations. } \\
\text { Students form their own networks with stakeholders and experts on their topic. } \\
\text { Lecturers often act as "brokers," helping students find relevant experts inside or outside the university. }\end{array}$ \\
\hline
\end{tabular}


of success has varied from no results at all to projects that continue long after the course has ended.

One project that sought to improve existing products was the development of healthy juices from fresh ingredients. Other examples included an extension of Apple's iTunes platform, "Hindi Tunes," which featured Hindi music, and a bike rental system in Groningen based on a similar initiative in Amsterdam. Other students invented new concepts such as a "city wardrobe" service (http://www.stadsgarderobe.nl/), in which bags and coats are stored for shoppers and others in the city center of Groningen. An example of a very complex and successful project was "Local Dreamers" (http://www. localdreamers.org/what-we-do/), which initiates social development projects in Ecuador with international volunteers.

Students receive little guidance for the project work in terms of assignments or scheduled activities. Individual assessment of the overall learning outcomes consists of three parts: an essay on a subject relevant to the student's project, a report about the new concept or product, and an oral presentation. In addition, the process of self-directed learning is assessed twice during the course by way of a learning report and an oral presentation (see also Cremers et al. 2014).

\section{Method}

After 11 iterations of the course, a questionnaire was sent to 100 alumni who had attended the course in iterations 1 (September 2008-February 2009) through 11 (September 2013February 2014) via LinkedIn (the selection of respondents was based on availability of a LinkedIn account). The total number of students who took the course was approximately 255. Fifty-eight alumni responded (representing a response rate of 58 percent). Every iteration was represented in the responses, with a peak of 18 in 2012.

The questionnaire contained six questions:

1. How do you look back on the course?

2. What did you get out of this course, either during your studies or your professional life?

3. Would you advise others to take this course?

4. When you look back, is there anything that you missed in the course?

5. Based on your experience as a working professional, do you have tips or recommendations for improving the course?

6. What grade would you give the course? (rated 1-10 with $10=$ excellent $)$

The responses were coded using the Atlas-ti program. For this study, answers relating to outcomes and effects of the course were of primary interest. Perception of the course also was included, since this is an indicator for "usability" - the extent to which the course was perceived as a useful and positive experience. The responses were analyzed according to the following criteria: perception of the course, effects on mind-set and/or behavior, and the intended outcomes of the course-that is, the five "job requirements" for a knowledge worker (skills in innovation, cross-boundary collaboration and learning, networking, professional behavior, and personal and professional development).

\section{Findings}

The respondents' perception of the course was positive, without exceptions. The mean score for the course was 8.6. Words that were often used in the responses were fun, freedom, useful, valuable learning experience, pleasure, and enriching experience. Several respondents stated that this was the most valuable course in their bachelor program. Students appreciated the fact that they could choose their own projects. One student said:

- "I finally got an opportunity to do something with my own ideas."

However, such an outlook did not mean that participation was always easy: a respondent commented that responsibility for one's own project was scary in the beginning, and collaboration with so many different people could be difficult. Most of the respondents stated that they would recommend the course to others, provided that such students were willing to deal with the freedom and take responsibility for their projects and learning process.

Learning Outcomes. All five "job requirements" were mentioned by the respondents: skills in innovation, cross-boundary collaboration and learning, networking, and professional behavior, as well as the opportunity for personal and professional development.

The most important skill in innovation that was mentioned can be characterized as "think less, do more." Participants mentioned that in their studies to date, they had been "programmed" to make plans, think, and rethink before taking action. By contrast, the design-thinking method calls for interaction with stakeholders and users of potential products by way of prototyping in every stage of the process, especially in the beginning. This was experienced as a valuable new mind-set that enabled participants to be less afraid to make mistakes:

- "The course taught me that I should not think too much of limitations, but to be open to possibilities. That's how I got my current job."

Another skill in innovation was related to creativity or out-ofthe-box thinking. Respondents mentioned techniques such 
as brainstorming that could enhance creativity. Creativity also could be stimulated by the perspectives of other people. Respondents stated that collaboration with peers from other study programs, with potential stakeholders and users, and with coaches and entrepreneurs enabled them to start looking at things in other ways and to be more open to different perspectives. As one respondent stated:

- "I look at things differently; now I am always looking for things that can be improved and how that could be done."

Some respondents indicated that they became aware of the value of networking and of how it is done. As one respondent commented:

"Networking is super important. Sometimes it does not yield a result immediately, but on the longer term it can be very useful."

The respondents did not mention professional behavior as such, but many of them mention "taking responsibility" and "being pro-active" or "entrepreneurial behaviour" as an outcome of the course. Others mentioned "growing up" during the minor:

"During the course I started thinking and working in a more professional way. I changed from a student into a working professional. Because of the freedom in the course you realize that you have to do it yourself. I can see this change in my peers as well."

Two aspects of personal and professional development appeared frequently in the responses: becoming aware of one's own development, and reflection. Several respondents mentioned the space that was available for reflection on actions and on strengths and weaknesses, for instance:

- "the course provided the opportunity and freedom to figure out what I wanted to do in relation to innovation and entrepreneurship, and in fact also with my future."

Effects on Students' Mind-set and Behavior. The course appeared to have an effect on the participants' further studies and professional career. One participant reported that this impact was negative, such that he now was less able to adjust to environments with many rules and limited freedom.

Many respondents reported that they had come to know themselves better, including their talents and weaknesses, as well as the direction in which to proceed. Two respondents indicated that they each "had become more the person that they would like to be." Other reported effects were mostly related to being more proactive and less afraid to contact people, and to taking steps to make things happen. For example, one respondent commented:
- "I dare say that I have this course to thank for my current job. During my job interview people kept asking about my project. I think the course provided my entry into the company that I work for now."

\section{Conclusion and Reflective Discussion}

Knowledge workers are needed who can solve complex problems collaboratively across disciplines, professions, and perspectives. These knowledge workers are lifelong learners who acquire and develop knowledge throughout their working lives. The findings seem to indicate that student-framed inquiry, as manifested in this course, along with (self)reflection, foster the development of relevant skills of these knowledge workers.

A reflective discussion with two lecturers from the course confirms that the following elements of the course can be considered the main contributors to the impact of the course:

- Students are put in charge of their own projects and their learning activities, and are encouraged to act and involve experts in early stages of their projects;

- Students come from diverse backgrounds;

- Students have regular feedback meetings and participate in celebrations of (small) successes, including a festival showcasing the research projects at the conclusion of the course; and

- Students have the sense of being part of a community of learners in which it is safe to make mistakes.

The biggest challenge for the lecturers was to find a balance between directing and inspiring the students, not being afraid to step back and allow the students to take charge. They learned, however, that it is important to establish the playing field and the rules of the game, especially during the first weeks of the course.

At the same time, it is very important that the lecturers help the students reflect on their personal and professional identity and talents. If the lecturers are role models in the sense that they, too, are learners who have insecurities, doubts, and ability to make mistakes, this seems to give students permission and inspiration to do the same. An example of a playful way of "celebrating mistakes" is a contest among students toward the end of the course, in which the "dumbest mistake" is awarded a small prize. Although the lecturers cannot (and do not wish to) hover over students, they participate with students in an online community or group. It has proven to be very effective (and enjoyable for all parties) if lecturers comment on students' posts regularly and also post their own reflections, tips, and suggestions. This way, the online community can be a valuable source of knowledge sharing and community building. 
The learning outcomes and impact mentioned by the course participants appear to be highly relevant for knowledge workers. This would strengthen the argument for broadening the definition of (undergraduate) research and inquiry, as was done in this study, to include the systematic development of practical solutions along with knowledge that is new to the students and the stakeholders. In addition, this study seems to confirm that open, discovery-oriented inquiry with a high level of student independence can enhance the capacity for student learning, thereby strengthening the teaching-research nexus (Spronken-Smith and Walker 2010). This would imply that courses for inquiry-based learning at the bachelor's level should include not only more traditional, discipline-oriented research skills and methods but also student-framed methods for design and discovery.

\section{Acknowledgments}

The author would like to thank Immo Dijkma and Jorg Andree, lecturers for the Da Vinci course, and the (former) students who responded to the questionnaire for their inspiring contribution to this research project.

\section{References}

Andriessen, Daan. 2014. Praktisch Relevant en Methodologisch Grondig? Dimensies van Onderzoek in het HBO. Utrecht, The Netherlands: Hogeschool Utrecht, Kenniscentrum Innovatie and Business.

Brew, Angela. 2010. "Imperatives and Challenges in Integrating Teaching and Research." Higher Education Research and Development 29: 139-150. doi: 10.1080/07294360903552451.

Brown, Tim. 2009. Change by Design: How Design Thinking Transforms Organizations and Inspires Innovation. New York, NY: HarperCollins.

Council on Undergraduate Research. "Mission Statement." Accessed May 4, 2016. http://www.cur.org/about_cur/

Cremers, Petra H. M., Arjen E. J. Wals, Renate Wesselink, and Martin Mulder. 2016. "Design Principles for Hybrid Learning Configurations at the Interface between School and Workplace." Learning Environments Research 19: 309-334. doi: 10.1007/s10984-016-9209-6.

Cremers, Petra H. M., Arjen E. J. Wals, Renate Wesselink, Nienke Nieveen, and Martin Mulder. 2014. "Self-directed Lifelong Learning in Hybrid Learning Configurations." International Journal of Lifelong Education 33: 207-232. doi: 10.1080/02601370.2013.838704.

EP-Nuffic. 2016. "Universities of Applied Sciences." Accessed November 21, 2016. https://www.studyinholland.nl/education-system/dutch-institutions/ universities-of-applied-sciences

Healey, Mick, Abbi Flint, and Kathy Harrington. 2014. Engagement through Partnership: Students as Partners in Learning and Teaching in Higher Education. Heslington, UK: The Higher Education Academy. doi:10.1080/136014 $4 x .2016 .1124966$.

Healey, Mick, and Alan Jenkins. 2009. Developing Undergraduate Research and Inquiry. Heslington, UK: The Higher Education Academy. doi: 10.1080/14703291003718976.

Instituut voor Marketing Management, Hanze University of Applied Sciences
(UAS). 2014. Studenthandleiding Minor Da Vinci. Unpublished student guidebook.

Levy, Philippa. 2011. "Embedding Inquiry and Research in Mainstream Higher Education: A UK Perspective." CUR Quarterly 32(1): 36-42.

Neary, Mike. 2014. "Student as Producer: Research-Engaged Teaching Frames University-wide Curriculum Development." CUR Quarterly 35(2): 28-34.

Spronken-Smith, Rachel, and Rebecca Walker. 2010. "Can Inquiry-Based Learning Strengthen the Links between Teaching and Disciplinary Research?" Studies in Higher Education 35: 723-740. doi: 10.1080/03075070903315502.

Stappers, Pieter. Jan. 2007. "Doing Design as a Part of Doing Research." In Design Research Now: Essays and Selected Projects, ed. Ralf Michel, 81-91. Basel: Birkhauser. doi: 10.1007/978-3-7643-8472-2_6.

Tynjälä, Paavi. 1999. "Towards Expert Knowledge? A Comparison between a Constructivist and a Traditional Learning Environment in the University." International Journal of Educational Research 31: 357-442. doi: 10.1016/s08830355(99)00012-9.

\section{Petra H. M. Cremers}

Hanze University of Applied Sciences, p.h.m.cremers@pl.hanze.nl

Petra Cremers is an educational consultant and researcher of hybrid learning configurations (living labs) at the interface of work and school-based settings at Hanze University of Applied Sciences. Her PhD research on hybrid learning configurations (HLC) at Wageningen University in the Netherlands focused on design principles for HLC, self-directed learning, and cross-boundary collaboration.

\section{doi: $10.18833 / \operatorname{curq} / 37 / 3 / 4$}

